\title{
Women's Experience of Sexual Harassment in Carpet Factories
}

\author{
Dhakal $\mathbf{G}^{1}$ \\ ${ }^{1}$ Master of Nursing, Women Health and Development, Institute of Medicine, Kathmandu, Nepal.
}

\section{ABSTRACT}

Background: Sexual harassment is a problematic issue where women and men work together. It is being recognized as a violation of human rights and human dignity which undermines the equality of opportunity and treatment between men and women. So, this study was conducted in Kathmandu which helps to find out women's experience of sexual harassment and its impact on them.

Methods: Descriptive study was conducted in six carpet factories, selected purposively. A semi-structured questionnaire was used to find out experience of sexual harassment and its impact on their job, mental and physical health. The organizational context and job context of those factories were also studied.

Results: From the study, 72\% workers had heard about Sexual Harassment and among them, $52 \%$ had faced it in their workplace. The most frequent type of sexual harassment was passing vulgar jokes, remarks or teasing obscenely $(87 \%)$. Twenty three percent of the workers felt disruption on their job, $61 \%$ were affected mentally and $8 \%$ were affected physically after harassment. All the workers felt provision and execution of penalty to the perpetrator. But none of the factory had policy on sexual harassment or none of the worker had complained about sexual harassment to the authority yet.

Conclusions: Female workers are very much vulnerable to sexual harassment by their male co workers. It negatively impacts their performance, mental and physical health. There should be sexual harassment policy in their organization to maintain a fair and productive working environment and implementation is must.

Key words: sexual harassment, working women, workplace, workers.

\section{INTRODUCTION}

Sexual harassment is any uninvited behaviors of sexual nature i.e. mild incidents to serious abuses which may be even forced sexual activity that creates an uncomfortable working environment for the recipient. ${ }^{1}$ In the humanitarian world everybody has the right to work in safe working environment with minimal conflict and violation of human right. It is emerged as a serious concern in workplaces. ${ }^{2}$

It is about expression of male power over female. It reminds women's vulnerability and lower status. ${ }^{3}$ Women are more likely to suffer sexual harassment because they lack power, social security and self confidence and socialized to suffer in silence.

Correspondence: Ms. Gita Dhakal Chalise, Syuchatar, Kathmandu, Nepal. Phone: 9841777554, Email: gita.dhakal@gmail.com. 
It has far reaching consequences to the victim, their family and employer organization, and other employees. Victims of harassment may develop significant physical, psychological and job related impacts.

The main purpose of this study was to find out the sexual harassment that working women go through in their workplace and its impact on them.

\section{METHODS}

Descriptive study was carried out in the six carpet factories of Kathmandu Valley. They were selected purposively. The duration of the study was four weeks.

Ethical approval was taken from the Institute of Medicine Nursing Campus. Verbal informed consent was taken from every selected subject. Subjects were assured for the anonymity and confidentiality of the information and allowed to refuse to participate in the study at any time if they wish.

The sample size were 101 working women, selected purposively. From those factories, only 101 women gave the permission for interview. All male workers and female who didn't give permission were excluded. To fulfill the objectives of the study, six carpet factories were also chosen as a research subject.

The research instrument was semi-structured interview questionnaire and had two parts. First part consisted of questions for the organizational manager which included number of male/female workers, gender of manager and supervisor, organizational policy on sexual harassment, previously reported harassment incidents and need for policy. Second part dealt with the questions for the workers which contained types of sexual harassment experienced by working women and its impact on job, mental health and physical health.

Analysis of personal information and other responses was done in sums of frequency (f), percentage (\%) and arithmetical mean $(x)$. By using the chi-square test; the relationship between age, ethnicity, educational status, marital status and years of job experiences to sexual harassment was analyzed. The level of significance was taken at $P<0.05$. The data was analyzed by using Statistical Package for Social Sciences version 11.5 for windows.

\section{RESULTS}

Out of the total 101 working women as sample, only 73 women $(72 \%)$ had heard about Sexual Harassment. Therefore data leading to the experience of sexual harassment and its impact on women was analyzed only for those 73 working women.
Out of 73 workers, $52 \%$ had faced sexual harassment in their working area and $48 \%$ had not. Similarly, $76 \%$ of unmarried workers and $42 \%$ of married workers had faced sexual harassment. The risk of having sexual harassment for an unmarried female worker is 4.36 times more than a married female worker. There is significant difference in proportion of sexual harassment among unmarried and married women $(P<0.05)$.

Sixty six percent female workers reported having sexually harassed by their co-workers followed by strangers (29\%) and immediate supervisors (5\%) respectively. Eighty seven percent said that the type of sexual harassment they faced was passing vulgar jokes, remarks or teasing obscenely. Nearly 3\% worker reported that the type of sexual harassment she faced was getting letters, telephone calls or obscene materials. Among the female workers, none had been the victims of the extreme situation of sexual harassment like display of sexual organ, pornographic pictures, attempted rape and rape (Table 1). Sixty eight percent workers reported that they faced the problem of sexual harassment while working within the factory and $32 \%$ workers faced such problem outside the factory. Half $(50 \%)$ of the workers said that they ignored the incidence. Similarly same percentage of the workers administered verbal or physical assault to the harasser and only $29 \%$ shared the incidence with friends or relatives close to them (Table 2).

\begin{tabular}{|c|c|}
\hline *Types of Sexual Harassment & Number (\%) \\
\hline Suggestive looks or gestures & $12(32)$ \\
\hline Touching sensitive body parts & $9(24)$ \\
\hline $\begin{array}{l}\text { Letters, telephone calls and sending } \\
\text { obscene materials }\end{array}$ & $1(3)$ \\
\hline Pressure for sexual favors & $11(29)$ \\
\hline Pressure for dating & $3(8)$ \\
\hline $\begin{array}{l}\text { Passing vulgar jokes, remarks or } \\
\text { teasing obscenely }\end{array}$ & $33(87)$ \\
\hline $\begin{array}{l}\text { Drawing vulgar words and pictures in } \\
\text { the toilet walls }\end{array}$ & $3(8)$ \\
\hline Showing pornographic pictures & - \\
\hline Showing sexual organs & - \\
\hline Attempted rape & - \\
\hline Rape/ sexual assault & - \\
\hline
\end{tabular}

*Multiple Responses 
Table 2. Reaction of the Respondents to Sexual Harassment: Immediate

\begin{tabular}{|c|c|}
\hline${ }^{*}$ Reactions & Number (\%) \\
\hline Ignore the incidence & $19(50)$ \\
\hline $\begin{array}{l}\text { Verbal or physical assault to the } \\
\text { harasser by themselves }\end{array}$ & $19(50)$ \\
\hline $\begin{array}{l}\text { Share the incidence with friends/ } \\
\text { relatives }\end{array}$ & $11(29)$ \\
\hline Crying after the incidence & - \\
\hline $\begin{array}{l}\text { Physical assault of harasser by other } \\
\text { people }\end{array}$ & - \\
\hline $\begin{array}{l}\text { Report the incident to the higher } \\
\text { authority }\end{array}$ & - \\
\hline File the case in the police station & - \\
\hline
\end{tabular}

Table 3. Effects of Sexual Harassment at Work after Facing Sexual Harassment

\begin{tabular}{|c|c|c|}
\hline *Effects at work & Number (\%) & Percent \\
\hline Feel like quitting a job & $8(89)$ & \\
\hline Lost interest in work & $4(44)$ & \\
\hline Staying away from the work & $1(11)$ & \\
\hline Coming late to the work & $1(11)$ & \\
\hline $\begin{array}{l}\text { Inability to concentrate on } \\
\text { the work }\end{array}$ & $3(33)$ & \\
\hline
\end{tabular}

*Multiple Responses

Among 38 female workers who had faced sexual harassment, 9 had experienced that the incident had some effect on their job. Eighty nine percent felt like quitting the job and others lost interest in work and inability to concentrate on work (Table 3 ).

Out of 38, 23 female workers reported having psychological problems after facing sexual harassment. Majority (74\%) of the workers reported that they became angry or violent towards the perpetrator, other $61 \%$ reported of feeling shame and guilt and $4 \%$ reported that she had experienced a suicidal thought because of harassment (Table 4).

Very few workers $3(8 \%)$ out of 38 reported that they had effect on physical health after experiencing sexual harassment incidents. Among them, all 3 reported anorexia was the major problem while the other effects reported were headache, faintness etc (Table 5).
Table 4. Psychological Effects after Harassment as Experienced By the Respondents

\begin{tabular}{|lc|}
\hline *Psychological Effects & Number (\%) \\
\hline Feeling of shame \& guilt & $14(61)$ \\
Getting angry for no reason & $11(48)$ \\
Feeling angry or violent towards the & $17(74)$ \\
perpetrator & $3(13)$ \\
Feeling of low self respect & $2(9)$ \\
\hline Feeling of loneliness & $12(52)$ \\
Disturbed sleep & $1(4)$ \\
Wanting to stay alone & $11(48)$ \\
Keep worrying & $1(4)$ \\
Feel like crying for no reason & $1(4)$ \\
Suicidal thoughts & $3(13)$ \\
\hline Irritability & - \\
\hline Feeling of helplessness & - \\
\hline Feeling of privacy being violated & - \\
\hline Feeling of going out of control & \\
\hline *Multiple Responses &
\end{tabular}

Table 5. Physical Effects as Experienced by Respondents After Sexual Harassment

\begin{tabular}{|lc|}
\hline *Physical Effects & Number (\%) \\
\hline Headache & $2(67)$ \\
Fatigue & $1(33)$ \\
Anorexia & $3(100)$ \\
Overeating & $1(33)$ \\
Weight loss & $1(33)$ \\
Restless & $1(33)$ \\
Faintness & $2(67)$ \\
Anxiety diarrhea & - \\
Body-ache & - \\
Difficulty in breathing & - \\
Weight gain & - \\
\hline *Multiple Responses
\end{tabular}

${ }^{*}$ Multiple Responses

Workers were also asked about how to prevent sexual harassment in the workplace (Table 6). On this question, $100 \%$ workers said that the organization should establish and enforce strong penalties to the perpetrator. Majority workers reported to establish friendly working environment within the organization and $63 \%$ reported to establish and display organizational policy on sexual harassment. Only few workers $(18 \%)$ said that government should play active role in the prevention of sexual harassment in private organization. 
Table 6. Preventive Measures of Sexual Harassment as Suggested by the Respondents.

\begin{tabular}{|lc|}
\hline *Suggestions & Number (\%) \\
\hline $\begin{array}{l}\text { Establish and display of organizational } \\
\text { policy on sexual harassment }\end{array}$ & $24(63)$ \\
$\begin{array}{l}\text { Have clear cut channels in the } \\
\text { organization for complaints }\end{array}$ & $8(21)$ \\
$\begin{array}{l}\text { Authority's vigilance in preventing } \\
\text { sexual harassment }\end{array}$ & $5(13)$ \\
$\begin{array}{l}\text { Provision and execution of penalty to } \\
\text { the perpetrator }\end{array}$ & $38(100)$ \\
$\begin{array}{l}\text { Establish friendly working environment } \\
\text { within the organization } \\
\text { Active role of trade unions in its } \\
\text { prevention }\end{array}$ & $29(76)$ \\
$\begin{array}{l}\text { Conducting awareness program for } \\
\text { workers } \\
\text { Aware about self defense techniques } \\
\text { among workers }\end{array}$ & $19(50)$ \\
$\begin{array}{l}\text { Active role of government in its } \\
\text { prevention in private organization }\end{array}$ & $7(18)$ \\
\hline *Multiple Responses & \\
\hline
\end{tabular}

The information gathered from the managers in regard to the organizational policy on sexual harassment and its implementation, revealed that, all carpet factory had male organizational managers and supervisors. None of the carpet factory had policy on sexual harassment and none had complained about sexual harassment to the authority as yet. Regarding need for policy, all managers felt the need for policy in their organization. Regarding the contribution for policy formulation, $67 \%$ said that they would contribute by participation in the workshop, $17 \%$ would provide financial support and $17 \%$ provide place to organize workshop.

\section{DISCUSSION}

The major age group working in the carpet factory was young adults of 20 to 39 years (69\%). A higher percentage (66\%) of Tamang ethnic group was represented in all carpet factories. The majority of the workers (76\%) were illiterate. The research findings indicate that $72 \%$ were aware about sexual harassment and among them 52\% had experienced it in their working area. The incidence may be found high but lack of legal remedies and fear of public humiliation discourage people to talk about sexual harassment. One study conducted by International Labor Organization (ILO) in Nepal showed that $40 \%$ of female employees were aware of sexual harassment and $54 \%$ of the female workers had experienced sexual harassment in the workplaces. ${ }^{1}$
While comparing the awareness of sexual harassment with respondents' age, there was no relationship found between age of the worker and experience of sexual harassment. This may be due to unequal distribution of sample size: teenage $\leq 19$ yrs $(27 \%)$ and adult $\geq 20$ yrs (73\%). But a study conducted in US showed that females under 30 years of age are more likely to be harassed than older women. ${ }^{4}$ While associating sexual harassment with marital status, it was found that unmarried workers might face sexual harassment more than married workers. This finding is supported by the US study which showed unmarried workers were most likely to experience sexual harassment than married workers. ${ }^{4}$ While associating work experience and sexual harassment, no relationship was found in this study but the study conducted in Malaysia revealed that workers who worked less than 3 years of employment might face more sexual harassment than workers who worked more than 3 years. ${ }^{5}$

About $66 \%$ of the respondents were harassed by their male co-workers followed by strangers and immediate supervisors. This finding can be compared with the General Federation of Nepalese trade Unions (GEFONT) study which also reported that majority of female workers are victimized by their co-workers in all forms of harassment followed by outsiders and managerial staffs. ${ }^{6}$ Eighty seven percent of workers had experienced verbal harassment like passing vulgar jokes, remarks or teasing obscenely. The other forms of harassment found in this study were suggestive looks or gestures, pressure for sexual favors and touching sensitive body parts.

In this study, $23 \%$ of workers experienced some disruption in their job and among them, 89\% respondents felt like quitting a job, $44 \%$ lost interest in work and 33\% inability to concentrate on work. The study revealed that $61 \%$ respondents were affected psychologically after harassment. Many harassed respondents reported feeling of angriness or violent (74\%), feeling of shame and guilt (61\%), disturbed sleep (52\%) and worrying (48\%). Sexual harassment also affects victim's physical health. But in this study, only $8 \%$ workers had been found affected physically by sexual harassment and exhibited some physical symptoms like anorexia, headache and faintness.

There is no specific law against sexual harassment in our country. According to study, all respondents told that there should be provision and execution of penalty to the perpetrator so that he can not repeat the same behavior repeatedly. Without any sexual harassment law and policy, it is impossible. By this, we can consider that there is urgent need for policy formulation against sexual harassment in our country. 
From the study, all selected carpet factory managers also felt the need for policy but neither there is national laws and policy on sexual harassment nor any of the selected factories has any code of conduct prohibiting the harassment. In Nepal, there are only two private companies: Hyatt Regency and Nepal Lever that have included a clause about sexual harassment in their employment policies. ${ }^{7}$

The duration of the study was only 4 weeks so that unable to select larger samples, difficulty locating carpet factories because of political transition and factory authority was not comfortable with strangers and found difficulty entering in carpet factories were some limitations of the study.

\section{CONCLUSIONS}

Women workers are victimized by verbal, non verbal and physical harassment, though the volume of physical harassment in this study was minimal. Co-workers are the major harassers to the women workers. The women suffer physically, mentally and socially but majority suffered mentally. Majority is facing sexual harassment at working but they often ignore the incidence. None of the worker filed cases against the harasser. Nepal has many laws in place to protect the rights of employees in relation to wages, hours worked and overtime but no laws and policy on sexual harassment except rape cases.

\section{ACKNOWLEDGEMENTS}

The researcher owes a special debt and heartfelt thanks to Prof. Dr. Indira Singh, Then Chairperson of the Research Committee and Prof. Dr. Sarala Shrestha for their expert opinions and valuable suggestions. The researcher wishes to acknowledge the Statistician $\mathrm{Mr}$
Umesh Raj Aryal and Epidemiologist Mr Megh Raj Banjara for statistical correction and Mr Bodh Raj Pant for English language correction.

The researcher would like to thank Carpet Association of Nepal for providing important information about the carpet factories. The researcher is especially grateful to all respondents who accepted this study and shared the experiences with researcher and also for different carpet factory managers for their cooperation for the study.

\section{REFERENCES}

1. International Labour Organization (ILO) and Forum for Women Law and Development (FWLD). Sexual Harassment at Workplace. Kathmandu: 2004.

2. Equal Employment Opportunity Commission (EEOC). Sexual Harassment. [online]. [cited 2008 Aug 10] Available from: URL: http://www.eeoc.gov./types/sexual-harassment.html.

3. Boland ML. Sexual Harassment: Your Guide to Legal Action. Naperville, Illionois: Sphinx Publishing; 2002.

4. The Illinois Department of Human Rights. Sexual Harassment in Illinois: A Comparative Study of Complaint Files. [online]. [cited 2008, Aug 14] Available from:URL http://www.state.il.us/dhr/ Publications/SXHRS_Rpt94.pdf.

5. Laxman L, Md Som H, Mohammed PM Heng LH. A Study on Sexual Harassment in Small \& Medium Enterprises of Malaysia. Malaysia: ILO; 2003

6. General Federation of Nepalese Trade Unions (GEFONT). Search for Alternatives (GEFONT/KAD Study Report on Women Workers Issues). Kathmandu: GEFONT; 2003

7. Forum for Women Law and Development (FWLD). Model Draft of Prohibition of Sexual Harassment of Women at Workplace Bill/ Ordinance. Nepal: FWLD; 2005. 